\author{
Review Article
}

\title{
A CRITICAL REVIEW ON CHOORNA VASTHI
}

\section{Nimisha Lathiff ${ }^{*}$, Indu.S ${ }^{2}$, Seena.S ${ }^{3}$}

${ }^{* 1}$ PG Scholar, ${ }^{2}$ Assistant Professor, ${ }^{3}$ Professor \& HOD, Department of Panchakarma, Govt. Ayurveda College, Tripunithura, Kerala, India.

\begin{tabular}{|c|c|}
\hline Article & BSTRACT \\
\hline story: & Sodhana chikitsa is an important treatment modality in Ayurveda in which the disease \\
\hline 2021 & route. Vamana, Virechana, Nasya, \\
\hline & Vasthi are the important bio purification measures. Once Doshas are eliminated through \\
\hline 21 & Sodhana procedures, it will never produce disease again. Among these Vasthi is considered \\
\hline $\begin{array}{l}\text { KEYWORDS: } \\
\text { Sodhana chikitsa, } \\
\text { Choorna vasthi. }\end{array}$ & $\begin{array}{l}\text { as important one and known as Ardha chikitsa. Vasthi can be given in various forms } \\
\text { according to the condition of disease and patient. By changing the additive drugs and their } \\
\text { proportion we can change the effect of Vasthi in our body for the concerned disease different } \\
\text { type of Vashti are mentioned in Brihatrayis based on disease and Dosha state. Choorna vasthi } \\
\text { also known as Ruksha vasthi is a type of Niruhavasthi mentioned in Chakrapani teeka and is } \\
\text { widely practiced nowadays in different clinical scenarios. But there is no direct reference } \\
\text { about this Vasthi available in Brihatrayis. This article is to provide an insight on Choorna } \\
\text { vasthi used in different conditions by analysing different studies done with it. }\end{array}$ \\
\hline
\end{tabular}

\section{INTRODUCTION}

Panchakarma play a vital role in Ayurvedic therapeutics and as such they occupy an important place in Ayurvedic medicine. Charaka samhita begins with the first Chatushaka on Bheshaja which is mostly and primarily devoted to the drugs used in Panchakarma. These five Karmas are Vamana (emesis), Virechana (purgation), Niruha (non unctuous enema), Anuvasana (unctuous enema) and Nasya (errhine therapy). Chakrapani further commented that, the word 'Karma' denotes extensive management and pronounced potency for elimination of impurities. Thus, classical Panchakarma is the comprehensive method of internal purification of the body by emesis, purgation, enema and errhine therapy.

Vasthi karma is included under five fold Panchakarma therapy in which the medicines are introduced to the colon through rectal route. Vasthi is mainly classified into Niruha vasthi, Anuvasana vasthi and Uttara vasthi. [1]

\begin{tabular}{|l|l|}
\hline \multicolumn{3}{|c|}{ Access this article online } \\
\hline Quick Response Code & \\
\hline Puttps://doi.org/10.47070/ijapr.v9i12.2188 \\
\hline
\end{tabular}

Niruha vasthi can again be divided into different types depending upon the Karmas it performs in the body. Vasthi is always useful in diseases caused by Vata, Pitta, Kapha and Rakta and in Samsarga sannipata conditions. ${ }^{[2]}$ Another notable advantage of vasthi is its quick action to produce the desired effects like Shodhana or Tarpana without causing any adverse effects. ${ }^{[3]}$ Acharya Charaka cited that Vasthi introduced in the colon acts upon the whole body and on every system. It draws out the impurities by its potency like sun evaporates the liquid from the earth by its heat. [4]

Choorna basthi can be considered as the type of Niruha vasthi. Acharya Chakrapani mentions Choorna basti comprising of Saindhava Lavana, Sneha, Choornas (Rasna, Vacha, Bilwa, Shatapushpa, Ela, Putika, Madanaphala, Pippali, Devadaru, Kushta), Ushnajala and Amladravya as the key ingredients. ${ }^{[5]}$ The only direct reference about this Vasthi available is in Chakrapani teeka of Charaka Samhitha.

The main purpose of Choorna vasthi in our body is to create Rukshata. So this Churna vasthi is also called as Ruksha vasthi. Vasthi like Kledahara vasthi, Grahanihara vasthi, Takravasthi etc., will produce Rukshata in our body. But apart from this Yogas, Vasthi with Choornas and Kashaya and Saindava (if needed) mixed and given in different disease conditions mainly in the Ama stage helps to produce Amapachana and Deepana effect in body. This effect can easily be achieved in the body when compared to the oral 
administration. Choornas taken for this type of Vasthi are mainly Deepana pachana in nature. If the Churnas containing Saindava as the ingredient are taken then no need to add it further. Drava dravya used for this Choorna vasthi is taken depending upon the disease condition. Kashayas, Dhanyamla etc., are taken as Drava dravya for this type of Vasthi.

\section{MATERIALS AND METHODS}

This study endeavours the critical analysis of Choorna vasthi that are under research works. There is no direct reference of Choorna vasthi available in classics. So this study was mainly done by compiling different articles and thesis works done on the topic Choorna vasthi. Data was collected and analysed to understand the conditions in which this Vasthi was administered and the drugs used with their probable effect in the disease. The effect of Vasthi on various parameters was also analysed. Books and other online materials were also considered.

\section{Review of Literature}

\section{Etymology of Vasthi}

The word Vasthi is derived from the root vas by adding Tich pratyaya

- Vasu nivase means to reside, to stay, to dwell.

- Vasu aachadane means to cover

Vasthi indicates the procedure in which the drugs are administered through the anal canal and it is retained for certain period of time, drag the waste materials from all over the body into the colon and eliminates them out of the body resulting in the desired effect.

\section{Definition of Vasthi}

- Vastheena deeyathe iti vasthi

- Vasthikarmam tu mutradharaputakena sadhyam karmam

The procedure in which medicine is administered by Vasthi (bladder).

\section{Different Vasthi's that are taken for evaluation}

Table 1: Different Type of Choorna Vasthi That are Taken for Evaluation

\begin{tabular}{|l|l|l|}
\hline No & Churna Vasthi yoga & Disease condition \\
\hline 1 & Sudarsana churna decoction and Vaiswanara churnam & In acute stage of RA \\
\hline 2 & Dhanyamlam and Vaiswanara churna vasthi & Pain and swelling in RA \\
\hline 3 & Guluchaydi kasayam and Vaiswanara churnam vasthi & Increased serum Creatinine and serum Urea level \\
\hline 4 & Rasnadi churna vasthi & Amavata \\
\hline 5 & $\begin{array}{l}\text { Vaiswanara churna, Dhanyamla and Rasnasapthaka } \\
\text { kasaya }\end{array}$ & Amavata \\
\hline 6 & Amruthadi Ruksha Vasthi & Acute stage of RA \\
\hline
\end{tabular}

Table 2: Dhanyamla Vaiswanara Vasthi

\begin{tabular}{|c|c|c|c|}
\hline No & Medicines & Quantity & Days administered \\
\hline 1 & Dhanyamlam & $300 \mathrm{ml}$ & \multirow{2}{*}{7 consecutive days } \\
\hline 2 & Vaiswanara churnam & $30 \mathrm{gm}$ & \\
\hline
\end{tabular}


Int. J. Ayur. Pharma Research, 2021;9(12):62-67

"Evaluation of Dhanyamla vaiswanara vasthi in reducing pain and swelling of the joints in Rheumatoid Arthritis" is a clinical trial conducted for the evaluation of Dhanyamla vaiswanara vasthi in reducing pain and swelling of the joints in Rheumatoid arthritis. The study design was interventional study- pre and post test without control group and the sample size was 30.

Table 3: Amruthadi Ruksha Vasthi

\begin{tabular}{|l|l|l|l|}
\hline No & \multicolumn{1}{|c|}{ Medicines } & Quantity & Days administered \\
\hline 1 & Amruthadi Kashyam & $300 \mathrm{ml}$ & \multirow{2}{*}{7 consecutive days } \\
\hline 2 & Shaddarana Churnam & $30 \mathrm{gm}$ & \\
\hline
\end{tabular}

"Clinical trial to evaluate the efficacy of Amruthadi Rukshavasthi in reducing signs and symptoms of Rheumatoid Arthritis" is a clinical trial to find out the effect of Vasthi in the inflammatory phase of Rheumatoid Arthritis. Due to unavailability of references regarding the Churna a focus group discussion was conducted related to this work. That enlightened various aspects of Ruksha vasthi and its literature basis.

Table 4: Rasnadi Churna Vasthi

\begin{tabular}{|c|c|c|c|}
\hline No & Ingredients & Quantity & Days administered \\
\hline 1 & Saindava lavanam & $6 \mathrm{gm}$ & \multirow{5}{*}{7 consecutive days } \\
\hline 2 & Eranda tailam & $75 \mathrm{ml}$ & \\
\hline 3 & Rasnadi churnam & $50 \mathrm{gm}$ & \\
\hline 4 & Chincha paste & $75 \mathrm{ml}$ & \\
\hline 5 & Ushna jala & $250 \mathrm{ml}$ & \\
\hline
\end{tabular}

"Effect of Rasnadi choorna vasthi in the management of Amavata in clinical correlation with Rhematoid arthritis- a case study" this study planned to evaluate the efficacy of Choorna vasthi in the management of Amavata. Acharya Chakrapani mentions Choorna vasthi comprising of Saindhava Lavana, Sneha, Churnas (Rasna, Vacha, Bilwa, Shatapushpa, Ela, Putika, Madanaphala, Pippali, Devadaru, Kushta), Ushnajala and Amladravya as the key ingredients were taken as medicines for this Vasthi.

Table 5: Rasna Sapthaka Vaiswanara Churna Vasthi

\begin{tabular}{|c|c|c|c|}
\hline No & Ingredients & Quantity & Days administered \\
\hline 1 & Vaiswanara churnam & $50 \mathrm{gm}$ & \multirow{3}{*}{$\begin{array}{c}9 \text { days } \\
\text { (modified Kalavasthi schedule) }\end{array}$} \\
\hline 2 & Rasna sapthakam kashayam & $200 \mathrm{ml}$ & \\
\hline 3 & Dhanyamlam & $100 \mathrm{ml}$ & \\
\hline
\end{tabular}

"Clinical study on Churna basthi administered in modified Kalavasthi schedule in Amavata" in this study a combination of Vaishwanara choorna, Rasna Saptaka Kashaya and Dhanyamla administered in Amavata. All subjects were administered with $350 \mathrm{ml}$ of Churna Basti and Anuvasana Basti with $80 \mathrm{ml}$ of Brihat Saindavadi Taila in modified Kala Basti Schedule.

Table 6: Sudarsana Kashya Vaiswanara Churna Vasthi

\begin{tabular}{|c|l|c|l|}
\hline No & \multicolumn{1}{|c|}{ Ingredients } & Quantity & Days administered \\
\hline 1 & Saindavam & $5 \mathrm{gm}$ & \multirow{2}{*}{7 consecutive days } \\
\hline 2 & Vaiswanara churnam & $30 \mathrm{gm}$ & \\
\hline 3 & Sudarsanam Kashyam & $300 \mathrm{ml}$ & \\
\hline
\end{tabular}

"Clinical study to assess the effectiveness of Vasthi with Sudarshana Kashaya and Vaiswanara churna in active inflammatory phase of Rheumatoid arthritis" a total of 30 patients were included in the study and given Vasthi continuously for 7 days. The content of Vasthi was Sudarshana Kshaya-300ml, Vaiswanra churna-30gm and Saindava churnam $5 \mathrm{gm}$.

Table 7: Guduchyadi Kashaya Vaiswanara Churna Vasthi

\begin{tabular}{|c|c|c|c|}
\hline No & Medicines & Quantity & Days administered \\
\hline 1 & Guluchaydi Kashyam & $300 \mathrm{ml}$ & \multirow{2}{*}{ 5 consecutive days } \\
\hline 2 & Vaiswanara Churnam & $30 \mathrm{gm}$ & \\
\hline
\end{tabular}


"The efficacy of Vasthi with a combination of Guduchayadi kasyam and Vaiswanara churnam on serum creatinine and serum urea in chronic kidney disease" in this study the combination of medicine Guluchyadi kashyam $300 \mathrm{ml}$ and 5 gm Vaiswnara churnam had given to total of 15 patients.

\section{DISCUSSSION}

While analysing the clinical conditions that are indicated for Choorna vasthi most of the studies deal with rheumatoid arthritis and its inflammatory phase. Vatasonitha and Amavata are the diseases correlated with the rheumatoid arthritis condition. The correlation of rheumatoid arthritis with Ayurveda diagnosis is still in the discussion phase. Because initial Ama or inflammatory condition is present in all type of Vatasonitha condition yet it is a Vata, Rakta vitiated condition. So the initial management of both the disease condition will be the same. Another indication seen in this analysis is application of Choorna vasthi in chronic kidney disease. In a focus group discussion related to one study concluded that Choorna vasthi can also be administered in the Ama stage or inflammatory phase of all clinical condition besides that it can be done in stroke condition immediately after stabilising, obesity and HIV conditions. Another study on different Vasthi formulation in low back ache conducted in VSPV Ayurved College, reported that Amruthotharam kashyam, Ganadharva hastyadi kashyam along with Vaiswanara churnam can be administered in patients with low back ache. No direct reference available for Ruksha vasthi in low back pain condition but adopting treatment principles of Amavata and Pakwasaya gata vata if the Dosa are lodged in Pakwasaya they should be eliminated through Vasthi and hence Vasthi has got role in such condition.

Dhanyamla vaiswanara vasthi is administered in the pain and swelling condition of Rheumatoid arthritis condition. Dhanyamlam by its Ushna, Tikshna and Vyavayi property is capable of penetrating the Sukshma srotas, does Sroto shodhana and helps in the spreading of active principles of Dhanyamlam and Vaiswanara choorna at Dhatu level. Thus Dhanyamlam acts as a vehicle to carry the Vaiswanara choorna having Deepana, Pachana properties through the Sukshma srotas. This facilitates Ama pachana at Dhatu level, relieves Dhatwagni mandya and enhances the Dhatwagni. Thus the primary Samprapthi vighatana of the Roga is initiated. By the synergetic action of Dhanyamla and Vaiswanara choorna having similar Virya, the Vasthi becomes more powerful and produces quicker results. As Ama pachana occurs, the inflammation starts to reduce. As a result, pain, swelling, tenderness and warmth of the joints and constitutional features like feeling of cold, lack of interest, fatigue and heaviness of body starts to reduce. The appetite of the patient increases due to Agni deepana and constipation is also relieved due to Vata anuloma. On analyzing the properties of the individual drugs, we can see that Yavani and Ajamoda are having Soolaprasamana property and Haritaki possess Vedanasthapana karma. Sunti and Haritaki are having Shothahara property and the drugs of Dhanyamla especially Thandula, Kulatha, Kangu and Kodrava are having Mutrala property. This may also potentiate the Vasthi in reducing the pain and swelling of joints.

Amruthadi ruksha vasthi indicated in the active inflammatory phase of Rheumatoid arthritis, and in inflammatory condition of Vatasonitha, as there is presence of Ama. Generalized weakness, heaviness of body, dyspepsia, oedema etc., shows the presence of Ama. The treatment aimed should do Dosha samana and Deepana pachana. Hareethaki has an active ingredient anthroquinone glycoside. The peculiar character of this ingredient is that it can be directly absorbed through gastro intestinal tract. The action of the anthroquinone is restricted to the large bowel. Hence their effect is delayed up to 6 hours or longer, if taken orally. It has been suggested that the common anthroquinone derivatives influence the ion transport across the colon cells by inhibition of chloride channels, it acts quicker if given through anal route. Hareethaki also have the Vathahara property. The Anulomana nature is effective in this disease condition. Nagara and Chithraka have effect in Annavahasrothas. Guduchi and Kutaja acts on Pureeshavaha srothas, Chithraka and Nagara stimulate Agni also. Deepana pachana effect of the drugs has the practical utility in management of the condition of Ama. Guduchi is said to be the best drug for Samshamana in Vatharaktha. Moreover, all these drugs are water soluble. Water soluble drugs are easily absorbed by large intestine. All these drugs are anti inflammatory too. Pakwasaya is the place of Vata. So there is fast effect by the action of drugs directly on Pakswasaya.

In single case study of the effect of Rasnadi churna vasthi in the management of Amavata, the patient was given Udwarthana followed by Sarvanga bashpa sweda prior to the administration of Vasthi. The Chikitsa explained for Amavata includes Shodhana as well as Shamana which includes Langhana, Deepana, Swedana, Virechana, Snehapana and Vasthi. In Amavata, Dosha's are deep routed in Sandhis and affects the whole body. In order to remove deep rooted Doshas, Vasti was selected for Shodana. In Choorna Basti Usnajala was mentioned in the place of Kwatha as Jala is the source of Rasa and it is the medium to reach the Dhatus. Usnajala has the property of Vata-Kapha Hara, Deepaniya and Vasti Shodhana. Chincha was used as Avapa and it is also Vata-Kapha Hara in nature. Eranda Taila is used as Sneha in the Basti due to its Vata-Kapha Hara property and is indicated in Moodha 
Vata condition. Due to all these qualities, Churna Basti is extremely beneficial in the Amavata.

Vaishwanara churna consists of Saindava, Yavani, Ajamoda, Nagara and Haritaki. Rasna Saptaka kashaya comprises of Rasna, Guduchi, Aragwadha, Devadaru, Gokshura, Erandamoola, Punarnava. Both these combinations have Vata-kaphahara, Deepaniya, Sothahara and Amahara properties. In this study, Dhanyamla is used as Amladravya and for Avapa which is having Amahara and Vatahara property. Brihat Saindavadi Taila is used for Anuvasana Basti. The base of this Taila is Eranda Taila and is mainly Vata Kapha Samaka. The Eranda Taila is medicated by different drugs which are also of Usna Virya, Agnidipana and Vatakapha Samaka. Thus, for Anuvasanabasti in the Amavata patients, the Eranda Taila seems to be best and so this preparation of Eranda Taila i.e., Brihatsaindhavadi Taila was selected. The contents of Brihat Saindavadi Taila are Saindava Lavana, Gaja Pippali, Rasna, Shatapushpa, Sarja Kshara, Marica, Kusta, Shunti, Souvarchala Lavana, Vida Lavana, Vacha, Ajamoda, Madhuka, Jeeraka, Pushkara Moola, and Kana. Basti administered with Ushna and Teeksna properties may aggravate the Vata. To pacify the aggravation of Vata, Anuvasana basti with Brihat Saindavaditaila is given in modified Kala Basti Schedule as Amavata is a Gambheera dhatugata vyadhi. According to authorities, after giving Niruha Basti in the morning, on the same day Anuvasana Basti can be given.

Guduchaydi kashyam and Vaiswanara churanam in CKD (Chronic Kidney Disease) has marked result in reducing the serum creatinine and urea after Vasthi administration and follow-up period. Guduchyadi kashayam is Kaphapittahara, there by Rakthaprasadana. Rakthadushti had mainly taken because of Kapha and Pitta vitiation and urine is the ultra-filtrate of blood. All Kaphapittahara drugs are kledahara. Kleda is the main pathology involved in this disease. It is presented as the Malarupavriddhi of Dhathus resulting in loss of integrity of Apyadhathus like Rasa, Raktha, Mamsa and Medas. So, Guduchyadi kashayam which is Kaphapittahara and Kledahara improves Dhathusthirathwam and Dhathwagnivriddhi. Some symptoms of CKD like Chardi, loss of appetite are also mentioned in the indication of Guduchyadi kashayam. Vaiswanara choornam which is best among Agnivardhanadravya, corrects the Dhatwagnimandyam there by prevent the formation of Dhathugathaama and produce Anulomanam. Hareethaki choornam comprises $50 \%$ of Vaiswanara choornam. It has an active ingredient chebulin an anthroquinone glycoside. Chebulin is considered to be the purgative principle in Terminalia chebula and it can be directly absorbed through the gastro intestinal tract. The action of the anthroquinone is restricted to the large bowel. It has been suggested that the common anthroquinone derivatives influence the ion transport across the colon cells by inhibition of its channels. The Anulomana nature is effective in this disease condition. Vasthi helps to correct the Apanavathavaigunyam, which is prominent in this disease. Vasthi is indicated for the Sodhana of Pakvasayagata pitta and Kapha. Here the disease is with Pakvasaya as Adhishtana and Pitta kapha doshadushti. So, this Vasthi expels the vitiated Pittakapha, and normalizes the movement of Vata.

Sudharshanm kashyam and Vaiswanara churnam, Churna vasthi is used in the active inflammatory phase of Rheumatoid arthritis. By the virtue of properties of drugs used in Vasti, first it causes Jataragni deepana, Koshtagata amapachana and Srotosodhana. Jataragni is the chief among three types of Agni because proper functioning of Bhutagni and Dhatwagni controlled by Jataragni. If Jataragni is strong Dhatwagni also become stronger. As Jataragni get corrected Dhatwagni also gets corrected automatically. This facilitates Amapachana at Dhatu level, relieves Dhatwagni mandya and enhances Dhatwagni and Samprapthi vighatana of disease get started. Srotosodhana actions of Vasti remove Margavarodha of Vyana vayu facilitate proper circulation throughout the body. As Amapachana occur at Koshta and Dhatu level and Dhatupaka reduces and inflammation starts to subside. Thus results in reduction of signs and symptoms of active inflammatory phase of rheumatoid arthritis.

\section{CONCLUSION}

- Rooksha vasthi can be administered in inflammatory phase of the disease, as it produces Deepana pachana effect in the body faster than the oral administration of medicine.

- Local Snehana procedure is not necessary prior to Rookshana vasthi administration, Swedana only needed.

- In most of the studies the amount of Vasthi dravya is taken as Padaheena $(300 \mathrm{ml})$ and the Churna $30 \mathrm{gm}$.

- Addition of Taila, honey not necessary in this Churna vasthi, if Churna contain Saindava as ingredient then no need to add further Saindava.

- Most of the studies done in inflammatory phase of Rheumatoid arthritis and the Churnas and Kashyas can be changed depending upon the condition of the patient and disease.

- Besides the above said practices Amruthotharam with Vaiswanara churnam, Gandharvahasthadi kashyam with Vaiswanara churnam, Kalayanakam kashyam with Vilwadi gulika, Rasndi churna in hot water these combinations are also practicing widely.

- Without using any Kashaya churnas ushnodakam alone gives adequate Rukshatha effect in body. 


\section{REFERENCES}

1. Hari Sadashiva Sastri Paradakara, editor. Ashtanga hridaya of Vagbhata with the commentaries Sarvangasundara and Ayurvedarasayana. 10th edition. Varanasi: Chaukhambha Surbharati Prakashan; 2017 Sutra sthana 19/2, p.270

2. Priya Vrat Sharma, editor. Susrutha Smhitha of Susrutha with English translation and Dalhanas commentaries. 9th edition. Varanasi: Chaukhambha Surbharati Prakashan; 2005 Chikitsa stana 25/6, p. 600

3. Priya Vrat Sharma, editor. Susrutha Smhitha of Susrutha with English translation and Dalhanas commentaries. 9th edition. Varanasi: Chaukhambha
Surbharati Prakashan; 2005 Chikitsa stana 25/1, p.599

4. Priya Vrat Sharma, editor. Susrutha Smhitha of Susrutha with English translation and Dalhanas commentaries. $9^{\text {th }}$ edition. Varanasi: Chaukhambha Surbharati Prakashan; 2005 Chikitsa stana 25/27, p.605

5. Ram Karan Sharma \& Vaidya Bhagwan Dash, editor. Charaka samhitha of Agnivesha text with English translation \& critical exposition based on Chakrpaniduttass Ayurveda Dipika. $10^{\text {th }}$ edition: Chaukhambha Surbharati Prakashan; 2009 sidhi stana 10/16-17 commentary. p.371

\section{Cite this article as:}

Nimisha Lathiff, Indu.S, Seena.S. A Critical Review on Choorna Vasthi. International Journal of Ayurveda and Pharma Research. 2021;9(12):62-67.

https://doi.org/10.47070/ijapr.v9i12.2188

Source of support: Nil, Conflict of interest: None Declared
*Address for correspondence Dr. Nimisha Lathiff

PG Scholar,

Dept. of Panchakarma,

Govt. Ayurveda College,

Tripunithura Kerala.

Email:

nimishalathiff@gmail.com

Phone: 8547177324

Disclaimer: IJAPR is solely owned by Mahadev Publications - dedicated to publish quality research, while every effort has been taken to verify the accuracy of the content published in our Journal. IJAPR cannot accept any responsibility or liability for the articles content which are published. The views expressed in articles by our contributing authors are not necessarily those of IJAPR editor or editorial board members. 